\title{
Smallholder Farmers' Responses to Rainfall Variability and Soil Fertility Problems by the Use of Indigenous Knowledge in Chipepo, Southern Zambia
}

\author{
Kabwe Harnadih Mubanga ${ }^{1,2}$ \& Bridget Bwalya Umar ${ }^{2}$ \\ ${ }^{1}$ Department of Geography, Centre for Environmental Studies, The University of Pretoria, Pretoria, South \\ Africa \\ ${ }^{2}$ Department of Geography and Environmental Studies, University of Zambia, Lusaka, Zambia \\ Correspondence: Kabwe Harnadih Mubanga, Department of Geography, Centre for Environmental Studies, The \\ University of Pretoria, Pretoria, South Africa. E-mail: kabwe.mubanga@zoology.up.ac.za
}

\author{
Received: February 8, 2014 Accepted: March 28, 2014 Online Published: May 15, 2014 \\ doi:10.5539/jas.v6n6p75 URL: http://dx.doi.org/10.5539/jas.v6n6p75
}

\begin{abstract}
The study conducted in Southern Zambia investigated smallholder farmers' use of indigenous knowledge to respond to rainfall variations and soil fertility problems. Farmer and key informant interviews and observations were employed to collect data. A total of 60 smallholder farmers and 6 key informants were interviewed. Chipepo lies in the low rainfall region of Zambia. Its upland area faces moisture stress and soil fertility problems compared to its valley areas located along tributaries of the Zambezi River. The annual flooding of the tributaries of the Zambezi River along the valley fields results in loss of crop yields. Farmers have responded to problems of low moisture in the upland fields and too much moisture in the river valley fields through crop diversification concentrated on three main food crops namely; maize, sorghum and bulrush millet. These differ not only in their moisture requirements but also in maturity periods. Drought tolerant early maturing crop varieties and off-farm activities enhance their resilience. Maize was planted in river valley fields due to its high water requirements while drought tolerant sorghum and millet were planted on upland fields. The farmers' knowledge of particular flowering plants helped forecast the onset of rains for purposes of early planting. Farmers with upland fields have adopted indigenous soil classification techniques based on vegetation types, soil colour, and texture and soil workability and utilize particular soils for specific crops. Integrating this indigenous knowledge into modern technologies will enhance smallholder farmers' resilience when faced with impacts of climate change and variability.
\end{abstract}

Keywords: indigenous response, resilience, climate variability, valley fields, upland fields

\section{Introduction}

Much of the effort aimed at improving the agricultural productivity of smallholder farmers in the developing world is focused on the use of modern technologies. Many believe that agricultural productivity growth, driven by research - induced technical change is essential to long run economic development (Alston et al., 2009). This is especially so, after the success of the Green Revolution, which took millions of smallholders out of poverty in South Asia and South America. Green Revolution technologies have been applied to modern science in developing countries' agriculture in order to find scientific solutions to ending hunger and food insecurity, through research spearheaded by a global agricultural research system, the Consultative Group on International Agricultural Research (CGIAR) and national agricultural research systems (Spielman and Pandya-Lorch, 2009:4). The products of both global and national agricultural research are disseminated to developing country farmers through National Agricultural Research Systems (NARS). NARS disseminate highly technical and scientific knowledge through a cadre of agents trained in modern scientific disciplines such as agronomy, crop and animal science, soil science, agro-economics and horticulture.

Initiatives such as the Alliance for a Green Revolution for Africa (AGRA), Comprehensive Africa Agriculture Development Programme (CAADP), Forum for Agricultural Research in Africa (FARA), are all aimed at increasing the productivity and incomes of smallholder farmers, and achieving food security in Africa (AGRA, 2011) through the promotion of Green Revolution technologies. However, a large majority of smallholder 
farmers do not have access to these technologies, and the knowledge and skills required for their use. Poor funding to NARS by developing country governments and under-investment by the private sector limit such access. Most smallholders in Sub Saharan Africa (SSA) do not have opportunities for receiving training in modern agricultural techniques from qualified extension agents. The ratio of Agriculture Extension Agents to farmers is very large, ranging from 1:1700 in 1992 (Kaunda, 2011) to 1:900 in 2011 (RESCAP, 2011). However this ratio is still far above the recommended 1:400 for Zambia (RESCAP, 2011). This has effectively limited smallholder farmers' access to scientific knowledge. It also has implications on how smallholder the farmers deal with the numerous challenges they face.

Despite its importance, the smallholder agriculture sector in Zambia, as is in most of SSA is faced with many challenges among which are climate variability (Chibinga, 2012; Fauchereau, Trzaska, Rouault, \& Richard, 2003; Nyanga, 2011; Umar, 2011) and poor soil fertility (Aagaard, 2011; Kurukulasuriya \& Mendelsohn, 2006).These challenges are most acute in SSA as most smallholders practice rain-fed agriculture, and soil fertility depletion is the fundamental biophysical cause for declining per capitafood production (Verde \& Matusso, 2014). These challenges are more pronounced among smallholder farmers as their limited financial resources precludes any intensive use of external inputs such as irrigation facilities, herbicides, and mineral fertilizers. This has encouraged smallholder farmers to respond by devising methods aimed at mitigating the impacts of rainfall variability and poor soil fertility using their indigenous knowledge. Indigenous knowledge is knowledge which has been gained over years of observation (Boateng, 2006). This knowledge is routinely ignored by researchers and extension agents in preference for rational science based knowledge, methods and skills. However, the over-reliance on scientific knowledge while neglecting the indigenous knowledge of smallholder farmers has for a long time been at the root of reduced agricultural productivity (Boateng, 2006).

It is therefore, important to encompass the indigenous knowledge of local farmers when designing and promoting agricultural technologies targeted at smallholder farmers. This approach has been supported by Nyanga et al. (2011) who observed that actors involved in promoting modern agriculture technologies like conservation agriculture technologies have often not taken into account perceptions of smallholder farmers on climate variability. This has resulted in promoting agriculture technologies among smallholder farmers which have not been supported by these farmers. This could have been one of the reasons for the slow adoption of these technologies by these farmers. The need for understanding and incorporating indigenous knowledge into modern technologies as well as decision making has increased with the realization that sustainable economic development depends on the indigenous knowledge of the local communities (Lwoga et al., 2010). This underscores the importance of a thorough understanding of indigenous methods of dealing with rainfall variability and poor soil fertility for the purpose of devising methods of improving upon them to enhance smallholder farmers' resilience. Little attention has been paid to integrating smallholder farmer's indigenous knowledge and farming methods based on such knowledge into the modern methods of dealing with smallholder agricultural problems in Zambia.

Research has shown that parts of Southern Africa which includes Angola, Zambia, Namibia, Mozambique and Malawi are predicted to record significant increases in heavy rainfall events (Usman \& Reason, 2004). Zambia has since experienced an increase in the frequency and intensity of droughts and floods over the last three decades (Banda, 2005). Rainfall variability has manifested itself in more intense and widespread droughts (Boko et al., 2007; Fauchereau et al., 2003; Yanda \& Mubaya, 2011). In the case of Southern Zambia where Chipepo, the study area, is, frequent and intense droughts have been recorded, although some parts have also experienced floods (Mubanga \& Umar, 2014). Generally, the climate of Zambia has been characterized by epic dry and wet periods. This intermittent availability of rainfall largely affects the normal growth of crops which has necessitated the development of mechanisms aimed at adapting to this variability in order to minimize crop yield losses.

The objective of this paper was to investigate how smallholder farmers in Southern Zambia have adapted to rainfall variability and poor soil fertility in the area by the use of their indigenous knowledge. Smallholder farmers were conceptualized as households which derive their livelihoods mainly but not exclusively from agriculture, predominantly utilize family labour in farm production, are characterized by a partial engagement in input and output markets, and are both producers and consumers of agricultural goods and services (Ellis, 1998; Umar, 2012).

\subsection{Description of the Study Area}

The study area, Chipepo is located in Southern Zambia. The area is situated about $70 \mathrm{~km}$ south east of Gwembe District near the shores of Lake Kariba. It is bordered by Lake Kariba in the south and the Zambezi escarpment 
in the north. The area lies on an altitude which varies between 500 and 650 meters above sea level. The relief of the area is gently undulating and is dissected by intermittent streams which are all tributaries of the Zambezi River (Madamombe, 2004). High flows in the Zambezi occur between January and May with peak flows occurring in March. The high levels in the river flow causes flooding especially on Zambezi sub-basins (Yamba et al., 2010) and the flood plains downstream the Bukata, Koma and Gwena Streams.

Generally, the land in Chipepo rises gently northwards from the Lake Kariba up to the steep slopes of the Zambezi escarpment which borders the area in the south (Figure 1). Clay soils occur on the flood plains of the tributary streams of the Zambezi River with deep vertisols of an alluvial nature also occurring within the flood plain. These flood plain soils are very fertile and form the most important agricultural soils (Aregheore, 2006). Conversely, the upland soils are mainly derived from coarse grained sandstones of the Karoo system characteristic of the middle Zambezi valleys (Mwila et al., 2008) and comprise dark brown to light brown sand and sandy clay which are less fertile for agriculture. Chipepo receives average uni-modal seasonal rainfall of $635 \mathrm{~mm}$ and has an average growing season of 80 to 120 days (Umar, 2012).

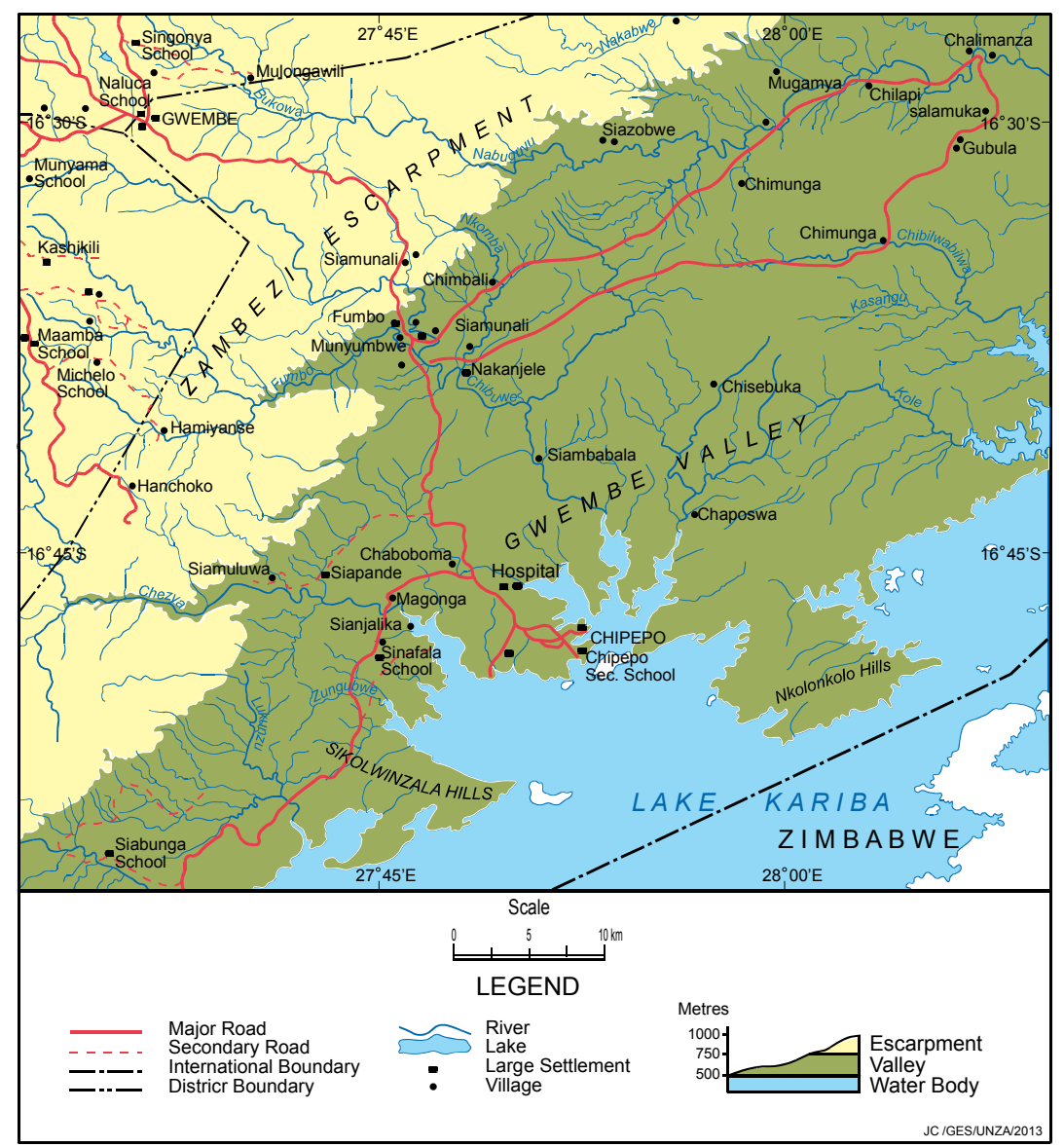

Figure 1. Topography of Chipepo area

\subsection{Agricultural Challenges in Chipepo Area}

Chipepo is largely an agricultural area and most of the people in the area depend on smallholder farming for sustenance. Even those in formal employment in most cases still engage in subsistence agriculture and nearly every household has a garden near the homestead. Despite being an agricultural community, the sector in the region has been in doldrums for several years due to the inadequate and intermittent rainfall received in the area (GRZ, 2007) which fails to sustain crop growth during the farming season. The mean annual rainfall of $635 \mathrm{~mm}$ received in Chipepo is less than the required rainfall for most Maize (Zea mays) varieties recommended for the region without supplement moisture from irrigation. Maize is the staple crop in Southern Zambia and requires an average of between $800 \mathrm{~mm}$ and $1000 \mathrm{~mm}$ of seasonal rainfall (GRZ, 2002). This problem is worsened by Southern Zambia's susceptibility to inter and intra-seasonal droughts (Umar \& Nyanga, 2011). In addition, the 
high evaporation rates in the area put a lot of moisture stress on plants as Chipepo is situated in the Gwembe valley area with a hot and dry climate and average temperatures go up to $33^{\circ} \mathrm{C}$. These climatic problems have contributed to the poor crop yields realized in the area. In years of above normal rainfall, the tributary streams of the Zambezi River flood the valley fields prior to their harvest resulting in crop losses. Furthermore, the sedimentary rocks of the Karoo system which characterize the area (Mwila et al., 2008) make agriculturally suitable soils difficult to find in Chipepo area away from the valley areas supplied by alluvium. It is common to find people with no valley fields cultivating long distances away from their homes because of not having enough fertile soils nearby. Fertile soils in the region are largely found along the Zambezi meanders or in the deltas of the Zambezi tributary rivers and are now under the waters of the Kariba Lake (Colson, 2011).

Farmers in Chipepo have adapted by devising methods of responding to rainfall variability and poor soil challenges. Their knowledge of the local environment may not entirely be based on direct recall of their own personal experiences but may also be based on knowledge passed down from generation to generation, that is, indigenous knowledge. For example, farmers may use sight and touch to determine the physical properties of the soil (Desbiez et al., 2004) or they may also use vegetation as an indicator of soil fertility (Kajoba et al., 1995; Desbiez et al., 2004).

\section{Methods}

\subsection{Data Collection}

Several methods of collecting data were employed in this study. These included desk studies, semi-structured and key informant interviews and observations. The data was collected between February and June 2011.

\subsubsection{Sampling}

A list of 325 smallholder farmers was obtained from the chief in the study area. Simple random sampling was used to select a sample of 60 farmers, representing $18.5 \%$ of the population.

\subsubsection{Semi-Structured Interviews}

Semi-structured interviews were used to collect information from the smallholder farmers. The information collected was on the agricultural problems faced related to rainfall and soil fertility. The interview schedules also collected data on local farming technologies and how these have been adopted as a response to the farmers' perceived challenges in agriculture. This method of data collection was preferred as it allowed the researchers to collect data efficiently as well as comprehensively since the researchers were able to probe for more information in cases where the information given was not sufficient. Interviews were conducted in Tonga, the local language of the study area by the first author who is very conversant with the language. The first author's ability to communicate with the respondents in the local language made it easier for them to open up to him and feel comfortable during the interviews, and also enabled him to adequately follow up on responses that needed probing.Having lived in the study area for several years before, the first author positioned himself as a local and was perceived as such by the respondents as well.

\subsubsection{Observations}

Data on the physical aspects of the environment was collected largely by observation. The physical aspects of the environment whose data was collected by observation included soils, vegetation, relief and drainage. The differences in soils types making up the valley fields as well as that making up the upland fields were observed. Furthermore, the types of vegetation in fields presumed to be suitable for particular crops were also observed. Observations were made to verify whether a farmer's pattern of agriculture reflected his/her soil classification method.

\subsubsection{Key Informant Interviews}

Information on agriculture in Chipepo area was collected through interviews with key informants from the Ministry of Agriculture and Livestock (MoAL), the Zambia National Farmers Union as well as longtime residents of the study area. A total of 6 key informants were interviewed on the types and varieties of crops cultivated in Chipepo, the nature of soil amendments used as well as how farmers responded to the intermittent rainfall the area received. The key informants were interviewed in English, the official language of Zambia.

\subsubsection{Desk Studies}

Desk analyses were conducted to gain a better understanding of the soils, vegetation, and drainage of the study area and to enrich the field observations made on the physical environment. For example, information on the drainage system of the area and the soil types have been documented and in such instances observation techniques only served to verify the secondary data on these physical features. 


\subsection{Data Analysis}

Responses from farmers on the measures employed to mitigate rainfall variability and poor soil fertility were analyzed using descriptive statistics in which the quantitative data were presented as percentages. Qualitative information from the semi-structured interviews with farmers and the key informant interviews was analyzed by summarizing the data into key themes, and noting the frequency with which each theme appeared.

\section{Results}

Two types of farming systems were observed among farmers in Chipepo area. One system involved crop cultivation in the river valley while the other was the growing of crops on upland areas. These two systems will be referred to as valley and upland farming respectively. Most leguminous, and drought tolerant crops such as common beans (Phaseolus vulgaris L.), groundnuts (Arachishypogea L.), bulrush millet (Pennisetum typhoides S.), sorghum (Sorghum bicolor L.), and water melons (Citrulluslanatus) were grown in the upland fields while crops such as maize and cotton (Gossypium hirsutum L.) were only grown in the valleys. Regardless of where the fields were, all the interviewed farmers reported experiencing climatic and soil problems in that the valley fields got flooded during periods of high rainfall when the Zambezi tributaries flooded while the upland fields had soil fertility problems.

\subsection{Agricultural Problems Pertaining to Rainfall and Soil Fertility}

All the farmers interviewed said they had been affected by poor rainfall distribution. Receiving below normal rainfall is a common occurrence and even when normal rainfall for the region is received; it is still insufficient to properly sustain maize and cotton. This commonly results in crop failures especially in upland fields which are located further away from the streams, hence not easily irrigated. On the other hand, in years of high rainfall, the tributary streams of the Zambezi River flood the valley fields especially those closest to Lake Kariba. This was largely the case during the 2007/2008 farming season (ZVAC, 2008). In such years, almost all the crops in the valley fields get washed away by these floods. Intra-seasonal droughts have also caused a lot of crop failures whether during seasons of high or low rainfall especially when they occur during germination or flowering (FAO, 2011; Umar \& Nyanga, 2011).

Problems of low soil fertility are characteristic of upland fields rather than valley fields. The flooding of the Zambezi River and its tributaries adds fertile alluvial deposits to the valley fields hence reducing the soil fertility problems in these fields.

\subsection{Use of Indigenous Knowledge as a Response to Rainfall Variability}

Experience among the smallholder farmers in Chipepo area has enabled them to devise indigenous technologies aimed at minimizing problems experienced in agriculture. Most of these measures have even been adapted and disseminated as 'modern technologies' although they have been used by local farmers for a long time as a response to rainfall challenges. The farmers were quite sensitive to droughts such that they could forecast the onset of rains using indicators such as the leafing and flowering of some plant species as well as the arrival of certain bird species. Understanding these indigenous innovations can be a powerful tool in knowledge management for the purpose of enhancing smallholder agricultural productivity.

All the interviewed farmers in the study area practiced a highly diversified type of agriculture which employed a variety of measures to reduce impacts of rainfall variability impeding their agriculture (Table 1).

Table 1. Farmers' response to rainfall challenges affecting rain fed agriculture, Chipepo Zambia

\begin{tabular}{ll}
\hline Response & Percentage (\%) \\
\hline Crop diversification & 100 \\
Cultivating drought tolerant crop varieties & 50 \\
Cultivating early maturing varieties & 53 \\
Early planting of crops & 100 \\
Engaging in off-farm and non-farm activities & 100 \\
\hline $\mathrm{N}=60$ & \\
\hline
\end{tabular}


Agriculture in Chipepo is largely characterized by the cultivation of four major food crops namely maize, bulrush millet, common beans, and groundnuts while cotton forms the major cash crop. Other crops grown include water melons, cucumbers (Cucumis sativus L.) and several other cucurbits. All the sampled farmers in the region have adapted by practicing crop diversification because it helps increase their household food security. This is so because during periods of below normal rainfall or drought periods, the drought tolerant crops survive and are harvested, ensuring some level of food security for the farming households. Maize (a staple crop) was always cultivated while most of the farmers also planted bulrush millet and cotton as these were believed to be drought tolerant and have been relied on to give some yields even in years of below normal rainfall for generations. Hence $50 \%$ of the farmers interviewed cultivated drought tolerant crops as part of their crop diversification strategies.

The time taken by each crop and each crop variety to mature is also another consideration by farmers in the study area when choosing which crop to cultivate. Given that Chipepo area has an average crop growing period of between 80 to 120 days with mean annual rainfall less than $800 \mathrm{~mm}$ (GRZ, 2007), the varieties of crops selected by farmers have to mature within this growing period. This has resulted in the prominent use of early maturing crop varieties (Table 1). For maize, different hybrid early maturing varieties were planted, while early maturing local varieties, known as Kampelya were also grown. The local varieties were preferred to hybrid varieties as they are believed to be not only more tolerant to droughts but also more resilient to weevil attacks and therefore store better.

In order to ensure that the early maturing varieties gave good yields, all the interviewed farmers were also practicing early planting of crops. Early planting entails planting crops immediately after the first effective rains of the farming season (CFU, 2009). The farmers used their knowledge of flowering plants which bloom at the beginning of the rain season to forecast the onset of rains and this was their cue for early planting. This ensured that maximum use of the intermittent rain was achieved as farmers planted their crops at the on-set of the rainy season.

In addition to the on-farm measures put in place by farmers to mitigate rainfall variability, all the farmers interviewed also engaged in non-farm and off- farm activities as a way of diversifying their livelihood sources. They engage in activities such as fishing, hunting, livestock rearing, selling crafts and hiring out themselves as casual labour. Others were part-time traders in either cattle or fish products.

\subsection{Use of Indigenous Knowledge as a Response to Challenges Pertaining to Soil Fertility}

Nearly all the management systems of crop residues observed among the farmers interviewed promoted the mining of soil nutrients (Table 2). The soil fertility problems among the upland fields could partly be attributed to these poor management practices among the farmers.

Table 2. Crop residue management practices employed in Chipepo Area, Zambia

\begin{tabular}{lc}
\hline Management System & Percentage of farmers \\
\hline Burning residues & 63 \\
Domestic use & 28 \\
Ploughing back into soil & 23 \\
Feeding to Animals & 65 \\
\hline $\mathrm{N}=65$ &
\end{tabular}

All the farmers interviewed practiced more than one management system hence the total percentage is more than 100 .

However, from all the interviewed farmers, only $23 \%$ ploughed back the crop residues at the beginning of the rainy season. These farmers said they had experienced higher yields as compared to others in the same area because of such soil management systems. This is because the ploughing back of crop residues recycles the nutrients back into the soil making it more fertile. The other forms of crop residue management systems employed in the study area involved the removal of crop residues, and concomitantly, nutrient mining. The farmers who used crop residues for domestic use said they used them for building granaries and roofing houses. Others fed them to livestock.

\subsection{Indigenous Soil Classification Methods}

Farmers in Chipepo area have adopted soil classification methods aimed at evaluating soil for growing specific crops. These farmers possess knowledge of soil suitability for each crop they grow. They use particular environmental characteristics to classify different soils. By matching their knowledge of one crop's requirements 
with environmental characteristics, farmers were able to classify soils based on suitability for specific crops (Table 3 ). Most of the farmers interviewed used more than one method of classification.

Table 3. Indigenous soil classification methods used in Chipepo, Zambia

\begin{tabular}{lc}
\hline Method of Soil Classification & Farmers employing classification system (\%) \\
\hline Use of vegetation & 57 \\
Touch method & 35 \\
Use of colour & 55 \\
Physical appearance & 17 \\
Workability & 18 \\
\hline $\mathrm{N}=100$ & \\
\hline
\end{tabular}

Most of the farmers (57\%) interviewed used vegetation type method to classify soil types. This method of classification works on the premise that there is a close relationship between the type of soil found in an area and the vegetation types that can grow on it. The farmers who use this method believe that the higher the plant species diversity in form of big trees and grasses, the more fertile the soils are. In addition, certain specific trees and grasses are assumed to grow where certain crops may grow well. For example, a field that has Bermuda grass (Cynodon dactylon) or Amaranthus hybridus locally known as bondwe, Lebombo (Julbernadia globiflora) or oriron wood tree (Androstachys johnsonii) is likely to have soils highly suitable for the cultivation of Maize and Cotton (Table 4).

Table 4. Soil suitability for selected crops using indigenous classification methods

\begin{tabular}{|c|c|c|c|c|}
\hline \multirow{2}{*}{ Crops } & \multicolumn{4}{|c|}{ Soil Classification Methods } \\
\hline & Vegetation & Touch & Colour & Workability \\
\hline $\begin{array}{l}\text { Maize } \\
\text { Cotton }\end{array}$ & $\begin{array}{l}\text { Cynodondactylon (aw), } \\
\text { Amaranthushybridus (aw), } \\
\text { Julbernadiaglobiflora (wp), } \\
\text { Androstachysjohnsonii (wp) }\end{array}$ & $\begin{array}{l}\text { Coarse texture } \\
\text { with fine material }\end{array}$ & $\begin{array}{l}\text {-Dark brown } \\
\text {-Black soils }\end{array}$ & $\begin{array}{l}\text { Slightly difficult to } \\
\text { work with }\end{array}$ \\
\hline $\begin{array}{l}\text { Pearl millet } \\
\text { Beans } \\
\text { Groundnuts } \\
\text { Watermelons }\end{array}$ & $\begin{array}{l}\text { Dense vegetation, Acacia } \\
\text { tortilis (wp), } \\
\text { Julbernadiaglobiflora (wp) } \\
\text { Acacia obtusifolia (pw), } \\
\text { Androstachysjohnsonii (wp) }\end{array}$ & $\begin{array}{l}\text { Dominantly course } \\
\text { texture }\end{array}$ & $\begin{array}{l}\text {-Light brown soils } \\
\text {-Light greyish soils }\end{array}$ & $\begin{array}{l}\text { Easily workable } \\
\text { soils }\end{array}$ \\
\hline $\begin{array}{l}\text { Sorghum } \\
\text { Finger millet }\end{array}$ & $\begin{array}{l}\text { Colophospermummopane (wp), } \\
\text { Androstachysjohnsonii (wp), } \\
\text { Brachystegiaboehmii (wp) }\end{array}$ & Fine texture & $\begin{array}{l}\text {-Red soils } \\
\text {-Light brown soils } \\
\text {-Light grey soils }\end{array}$ & $\begin{array}{l}\text { Difficult to work } \\
\text { with }\end{array}$ \\
\hline
\end{tabular}

(aw)-Annual weed (pw)-Perennial weed (wp)-Woody plant.

Another indigenous method of classifying soils involved the use of touch to feel the texture and classify soils accordingly. Under this method, a farmer rubs a soil sample between the fingers to determine the dominant particle sizes making up that soil. Crops requiring a lot of water are planted in soils with smaller particles implying high water holding capacity and vice versa.

The farmers interviewed indicated that the ease or difficulty of tilling soils provides another method of classification. Soils that stick to farming implements like ploughs and hoes are said to be difficult to work with while those that do not stick are easy to work with. However, farmers view sandy soils to be difficult to work with because while sandy soils do not stick to implements they hinder the smooth movement of oxen when ploughing. Only $18 \%$ of the farmers interviewed reported having used this method. With the exception of sandy soils, soils that are difficult to work with are poorly drained and vice versa. 
Soil colour was yet another attribute farmers used to classify soils. The underlying principle is that the colour of the soil is an indicator of the type of minerals present in the soil. Thus, $55 \%$ of the interviewed farmers believed that dark soils locally known as nkombolole are more fertile than lighter soils locally known as sebwa.

\subsection{Soil Improvement Methods}

Several methods were used by farmers to improve soil fertility in the upland fields (Table 5). Application of manure is especially common on fields which are close to homesteads since nearly all the farmers rear livestock and are able to utilize kraal manure for soil improvement. The focus on fields close to the homestead is due to the bulkiness of the manure, which makes it difficult to transfer it to fields that are far from the homesteads.

Table 5. Farmer use of indigenous soil improvement methods, Chipepo, Zambia

\begin{tabular}{lc}
\hline Method of soil improvement & Percentage of farmers employing method \\
\hline Application of manure & 30 \\
Crop rotation & 35 \\
Shifting cultivation & 21 \\
Fallowing & 18 \\
Contouring & 13 \\
Application of artificial fertilizer & 15 \\
\hline $\mathrm{N}=60$ & \\
\hline
\end{tabular}

Although $35 \%$ of the farmers said they practiced crop rotation, the rotation was just about a sequential change in the types of crops grown on a field without necessarily following a systematic pattern of cereals being planted after legumes. Some farmers $(13 \%)$ in the area also practiced contouring. This is because the steep slopes that characterize the upland fields make them prone to sheet erosion. The contours protect the top soil from being washed away by surface run-off.

For farmers who had large plots of land which allowed for fallowing without risking their subsistence, shifting cultivation was common. Farmers tended to let their fields lie fallow when continued and significant reductions in yields were recorded. They then moved to 'new' lands. At least $21 \%$ of the farmers interviewed reported to have used their fields for 3-4 years before shifting; leaving them to fallow for three years after which they started using them again. To aid the regeneration process, farmers cut big trees at about 1.5 meters height when clearing trees. Artificial fertilizers where used by only $15 \%$ of the farmers interviewed. This was due to their high cost and unavailability in the study area. The farmers that used these artificial fertilizers combined them with livestock manure in order to increase the quantities of nutrients added.

\section{Discussion}

Smallholder farmers in Chipepo are aware of their area's rainfall variability from experience, hence the response to the challenge. It is not only occurrences of extreme events such as droughts or extreme rainfall that are important to their agricultural sustainability, but more common occurrences such as intra-seasonal rainfall variability (Thomas et al., 2007), the timing of the onset of first rains and rainfall distribution within the growing season (Mortimore \& Adams, 2001). The use of crops with different agronomic characteristics ensures that some of the crops sustain their agility even during periods of droughts. The cultivated crops differ not only in their moisture requirements but also in their maturity periods and vulnerability to a wide range of pests. This crop diversification reduces the possibility of complete crop failure in any given year and ensures that farmers in the area have a subsistence crop to fall back on in instances when maize does not do well. Given the dominance of maize cropping by smallholder farmers in Zambia (Umar \& Nyanga, 2011) and the vulnerability of maize to short periods of intra seasonal drought as well as to early floods the farmers would be routinely affected if they did not come up with such responses. These events have very little effects on pearl millet which is drought tolerant and hence is usually planted on the upland fields. Although pearl millet and sorghum were introduced into Southern Zambia in the late 19th century, agricultural policies focused on maize cultivation by both the colonial and post-independence government led to major reductions in the cultivation of these crops in preference for maize. The provision of maize and artificial fertilizer subsidies by the central government since the 1970s led to maize cultivation on over 
$90 \%$ of the cultivated land in southern province. With the increasing rainfall variability, this has been gradually changing with crop diversification getting more attention.

Nearly two decades ago, Kajoba (1995) had advanced similarly effective traditional methods of determining in which soil types to grow several different crops. However, just locating the type of soil whose texture is best suited for a particular crop does not offer farmers solutions for low soil fertility. Modern farming technologies such as those packaged under conservation agriculture which involves a series of sound land husbandry practices which minimize soil disturbance, keep soils permanently covered with organic matter and sequentially rotate crops(Chappel \& Agnew, 2004) may address the limitations of traditional methods. For instance, while farmers practice crop rotation, it is not done in a systematic way as they just grow different crops on a particular field from year to year, and do not pay attention to the ability of the crops being rotated to be mutually beneficial. Soils identified by farmers using traditional methods may sustain them for 2-3 growing season after which the crop yields significantly decline and soil amendments or fallowing are needed. Farmers in the study area responded to this challenge by opening up forested lands for agriculture. This is where integrating some modern technologies such as retention of crop residues and minimum tillage would complement traditional methods of agricultural land management. As seen in the traditional methods, the practice of mining nutrients from the soil was common as only $23 \%$ were retaining the crop residues on the fields. This poses a further limitation on traditional methods and exposes the challenges of mixed crop-livestock system of farming in that a farmer may trade off crop residue manure for livestock feed. The farmers may have the knowledge of best practices in agriculture but, as evidenced by the example of crop residues, they find it difficult to utilize this knowledge due to other challenges such as finding animal feed during the dry season. This places a limitation on the farmer's practice of indigenous knowledge. An advantage of integrating traditional methods and modern technologies is also in the ease with which traditional farmers adopt methods that are locally driven. Nyanga (2011) reported that adoption of conservation agriculture in Zambia has been very low and many of those who have adopted it have expected to receive some material incentives for adopting it. If the promoters of such modern technologies would engage the locals and incorporate their local methods, these technologies would have a higher adoption rate as they would be locally driven.

Forecasting of the onset of rainfall using flowering plants may help farmers to practice early planting, which is advisable in the area and was said to be practiced by most farmers. However, properly executed early planting is hard to achieve due to spatial and temporal variations in rainfall within the area. This is a challenge which even scientific weather forecasts by Zambia's Meteorological Department have failed to address. Farmers complained that the weather forecasts are too generic and not helpful for decision making at local level. Furthermore, there is considerable uncertainty about the potential impact of climate change on agriculture (Bazzaz \& Sambroek, 2005). These impacts are not only expected to affect soil fertility (Bazzaz \& Sambroek, 2005) but are also likely to affect the timings of the onset of rains as well as the nature and composition of plants in many areas. Hence the use of plants to forecast the onset of rainfall may not provide farmers with long-term resilience if the climate uncertainty scenario is considered.

\section{Conclusion}

The major agricultural problems faced by smallholder farmers in Chipepo area are those related to low yields due to rainfall and soil fertility induced crop failures. The relatively low rainfall received and its poor distribution as well as flooding of the Zambezi River on the valley fields coupled with poor soil fertility on the upland fields is among the reasons for crop failures. Farmers have devised response measures to minimize the problem of yield losses due to low moisture in the upland fields and excessive moisture in the river valley fields by practicing crop diversification. This is done by concentrating on three main food crops namely; maize, sorghum and pearl millet which all differ not only in their moisture requirements but also in their maturity periods. The farmers also practice early planting based on their indigenous methods of rainfall forecasting through observations of certain flowering plants. As a measure of reducing crop failure from floods along the Zambezi river, the farmers locate some of their fields at considerable distances from the river banks as well as planting crops not easily affected by floods in the valley fields. The problem of poor soil fertility on the upland fields has been handled by the farmers adopting indigenous soil classification techniques based on vegetation types, soil colour, texture, and soil workability. These methods help farmers identify the best soils for each of the crops they grow. Overall, it was concluded that long-term resilience by farmers could only be achieved by integrating the traditional methods with the modern technologies with sound land husbandry practices considering the discussed limitations of traditional methods. The integration process can be achieved if promoters of modern technologies engage the locals and incorporate some of their traditional methods in order to make the modern technologies locally driven for easy adoption. 


\section{References}

Aagaard, P. J. (2011). Conservation Farming, Productivity and Climate Change. Zambia: Conservation Farming Unit.

AGRA. (2011). AGRA UPDATE: Soils-Nairobi. Alliance for a Green Revolution in Africa.

Aregheore, E. M. (2006). Zambia. Country pasture/forage resource profiles. Retrieved February 21, 2008, from http://www.fao.org/ag/agp/AGPC/doc/Counprof/zambia/zambia.htm

Banda, K. A. (2005). Impact of Rainfall Variability and Agricultural Factors on Maize Yields in Lusaka Province, from 1976 to 2002. Geography Department, The University of Zambia, Lusaka.

Bazzaz, F. A., \& Sombroek, W. G. (2005). Global climatic change and agricultural production: An assessment of current knowledge and critical gaps. Rome, Italy, Food and Agriculture Organisation of the United Nations (FAO).

Boateng, W. (2006). Knowledge management working tool for agricultural extension practice: the case of Ghana. Knowledge Management for Development Journal, 2(3), 19-29.

Chappell, A., \& Agnew, C. T. (2004). Modeling climate change in West African Sahel rainfall (1931-90) as an artifact of changing station locations. International Journal of Climatology, 24(5), 547-554. http://dx.doi.org/10.1002/joc.1021

Chibinga, O. C., Musimba, N. R. K, Nyangito, M. M, Simbaya, M. M., \& Daura, M. T. (2012). Climate variability; enhancing adaptive utilization of browse trees for improved livestock production among agro-pastoralists communities in Southern Zambia. African Journal of Environmental Science and Technology, 6(7), 267-274. http://dx.doi.org/10.5897/AJEST11.329

Colson, E. (2011). Resilience as a Way of Life in Gwembe Valley: Research Institute for Humanity and Nature (RIHN).

Desbiez, A., Matthews, R, Tripathi, B., \& Ellis-Jones, J. (2004). Perceptions and assessment of soil fertility by farmers in the mid-hills of Nepal. Agriculture, Ecosystems and Environment, 103, 191-206. http://dx.doi.org/10.1016/j.agee.2003.10.003

FAO. (2011). Climatic Risk Analysis in Conservation Agriculture in Varied Biophysical and Socio-economic Settings of Southern Africa. Johannesburg, Regional Emergency Office for Southern Africa (REOSA).

Fauchereau, N., Trzaska, S., Rouault, M., \& Richard, Y. (2003). Rainfall variability and changes in southern Africa during the 20th century in the global warming context. Natural Hazards, 29(2), 139-154. http://dx.doi.org/10.1023/A:1023630924100

GRZ. (2002). Maize Production Guide, Public Service Capacity Building Project. Management Division, Soils and Crop Research Branch (SCRB) and Ministry Of Agriculture and Cooperatives (MACO).

GRZ. (2007). The National Adaptation Programme on Action, Ministry of Tourism, Environment and Natural Resources.

GRZ. (2007). The National Adaptation Programme on Action, Ministry of Tourism, Environment and Natural Resources.

GRZ. (2010). The Sixth National Development Plan for Zambia 2011-2015. Lusaka, Ministry of Finance and National Planning.

JAICAF. (2008). The Maize in Zambia and Malawi. Akasaka, Japan Association for International Collaboration of Agriculture and Forestry.

Jain, S. (2007). An Empirical Economic Assessment of Impacts of Climate Change on Agriculture in Zambia. The World Bank Policy Research Working Paper 4291. Retrieved from http://papers.ssrn.com/sol13/appers.cfm

Kajoba, G. M., Volk, J, Ngenda, G., \& Mwanza, A. (1995). Sustainable mangemnet of village resources and enriching commercialisation in Mumena, Solwezi Distict, North Western Zambia. Solwezi, African Development Foundation.

Kurukulasuriya, P., \& Mendelsohn, R. (2006). Crop selection: adapting to climate change in Africa. CEEPA Discussion Paper No. 26. Pretoria, Centre for Environmental Economics and Policy in Africa, University of Pretoria. 
Lwoga, E. T., Ngulube, P., \& Stilwell, C. (2010). Understanding indigenous knowledge: Bridging the knowledge gap through a knowledge creation model for agricultural development. South African Journal of Information Mangement, 12(1), 1-8.

Madamombe, E. K. (2004). Integrated Flood Management Case Study Zimbabwe: Flood Management Practices-Selected Flood Prone Areas Zambezi Basin. WMO/GWP Associated Programme on Flood Management.

Mubanga, K. H., \& Umar, B. B. (2014). Climate Variability and Change in Southern Zambia: 1910 to 2009. 2014 International Conference on Intelligent Agriculture (ICOIA) (pp. 94-100). IPCBEE. Hong Kong: IACSIT Press.

Nyanga, P. H., Johnsen, F. H., \& Aune, J. B. (2011). Smallholder Farmers' Perceptions of Climate Change and Conservation Agriculture: Evidence from Zambia. Journal of Sustainable Development, 4(4), 73-85. http://dx.doi.org/10.5539/jsd.v4n4p73

Sitko, N. J., Chapoto, A., Kabwe, S., Tembo, S., Hichaambwa, M., Lubinda, R., ... Nthani, D. (2011). Technical Compendium Descriptive Agricultural Statistics and Analysis for Zambia in Support of the USAID Mission's Feed the Future Strategic Review. LUSAKA, ZAMBIA, FOOD SECURITY RESEARCH PROJECT, WORKING PAPER No. 52.

Umar, B. B. (2012). From Maize Mono-cropping to Conservation Agriculture: A Multi-perspective Analysis of Smallholder Conservation Agriculture in Southern, Central and Eastern Zambia. Department of International Environment and Development Studies. Norway, Norwegian University of Life Sciences PhD.

Umar, B. B., \& Nyanga, P. H. (2011). Conservation agriculture and rainfall variability in Zambia: is CA a promising option for responding to droughts and floods? 5th World Conference on Conservation Agriculture. Brisbane Australia, WCCA/Farming Systems Design.

Umar, B. B., Aune, J. B., Johnsen, F. H., \& Lungu, I. O. (2011). Options for Improving Smallholder Conservation Agriculture in Zambia. Journal of Agricultural Science, 3(3), 50-62. http://dx.doi.org/10.5539/jas.v3n3p50

Usman, M., \& Reason, C. J. C. (2004). Dry spell frequencies and their variability over Southern Africa. Clim Res, 26, 199-211. http://dx.doi.org/10.3354/cr026199

Verde, B., \& Matusso, J. (2014). Phosphorus in Sub-Sahara African Soils - Strategies and Options for improving available Soil Phosphorus in Smallholder Farming Systems: A Review. Academic Research Journal of Agricultural Science and Research, 2(1), 1-5.

Yamba, F. D., Zhou, P., Cuamba, B., Walimwipi, H., \& Mzezewa, C. (2010). Impact of Climate Change on Hydro-Electric Generation in the Zambezi River Basin. Eskom Holdings Ltd.

Yanda, P. Z., \& Mubaya, C. P. (2011). Managing a Changing Climate in Africa. Local Level Vulnerabilities and Adaptation Experiences. Dar-es-salaam, Mkuki na Nyota.

ZVAC. (2008). Multi-sectoral in-depth vulnerability and needs assessment. Lusaka Zambia Vulnerability Assessment Committee (ZVAC).

\section{Copyrights}

Copyright for this article is retained by the author(s), with first publication rights granted to the journal.

This is an open-access article distributed under the terms and conditions of the Creative Commons Attribution license (http://creativecommons.org/licenses/by/3.0/). 